\title{
In-Vitro Antidiabetic and Antioxidant Activity of Various Leaf Extracts of Detarium microcarpum
}

\author{
Jane David ${ }^{1 *}$, Ezekiel O. Afolabi ${ }^{2}$, Stephen O. Ojerinde ${ }^{2}$, Paul N. Olotu ${ }^{3}$, Francis M. Agwom², Ukpe Ajima ${ }^{2}$ \\ ${ }^{1}$ Department of Medical Biotechnology, National Biotechnology Development Agency, Abuja, Nigeria. \\ ${ }^{2}$ Department of Pharmaceutical Chemistry, Faculty of Pharmaceutical Sciences, University of Jos, Jos, Nigeria. \\ ${ }^{3}$ Department of Pharmacognosy \& Traditional Medicine, Faculty of Pharmaceutical Sciences, University of Jos, Jos, Nigeria.
}

\section{ARTICLE INFO}

Article history:

Received on: 12/11/2016

Accepted on: 10/01/2017

Available online: 30/06/2017

Key words:

Antidiabetic, Antioxidant,

Detarium microcarpum,

DPPH, $\alpha$-amylase,

$\alpha$-glucosidase.

\begin{abstract}
Detarium microcarpum commonly known as "sweet detar" has been used for centuries in Nigerian traditional system of medicine for the treatment of diabetes. The present study deals with the scientific evaluation of the invitro alpha amylase, alpha glucosidase and the antioxidant potential of various leaf extracts of the plant by examining the free radical scavenging activity on DPPH using Rutin, Gallic acid and Ascorbic acid as standards. The Total Phenolic Content (TPC) and Total Flavonoid Content (TFC) of the leaf extracts were also determined using standard methods. The ethyl acetate, aqueous, and crude leaf extracts of D. microcarpum showed a significant amount of phenolic content $2014.22 \mathrm{mg}, 933.33 \mathrm{mg}$ and $766.81 \mathrm{mg}$ of GAE/g of extract respectively. Total flavonoid content in the ethyl acetate, aqueous and crude leaf extracts was discovered to be also high with values of $132.90 \mathrm{mg}, 30.50 \mathrm{mg}$ and $49.50 \mathrm{mg}$ of rutin equivalent (RE)/ g of extract respectively. The radical scavenging activities of extracts were significantly higher at all concentrations used than the standard compounds. The half-maximal inhibitory concentrations $\left(\mathrm{IC}_{50}\right)$ of $D$. microcarpum crude and aqueous leaf extracts on $\alpha$-amylase and $\alpha$-glucosidase were lower than that of the ethylacetate fraction but all were higher than that of Acarbose. The present study provides evidence that the leaf extract of D. microcarpum is rich in flavonoids and other polyphenolic compounds and also possesses potent alpha amylase, alpha glucosidase and antioxidant activities and this may justify its use in ethnomedicine in the management of diabetes.
\end{abstract}

\section{INTRODUCTION}

Diabetes mellitus (DM) is a metabolic disorder characterized by chronic hyperglycemia with disturbances in carbohydrate, lipid and protein metabolism, resulting from defects in insulin secretion, action or both (WHO, 1999). The disease is a major global health concern and It is projected that by 2030 , the number of diabetic patients will increase to about 366 million (Shaw et al., 2010), with type 2 diabetes accounting for $90-95 \%$ of the cases. Despite the advent of oral hypoglycemics and other synthetic drugs, the search for new agents which are less toxic, cheaper and possessing better efficacy is still a matter of great priority. Natural products constitute a large and useful source of drugs for managing

\footnotetext{
* Corresponding Author

Jane David, Department of Medical Biotechnology,

National Biotechnology Development Agency, Abuja, Nigeria.

Email: kanjane41 @ yahoo.com
}

numerous diseases and the large number of plants used to manage diabetes in various countries across Africa may provide a useful source for the discovery of new compounds that can be used as lead compounds for further drug development or as simple dietary adjuncts to existing therapies (Hostettmann et al., 2000; TraBi et al., 2008). Detarium microcarpum (Fabaceae) is an African leguminous medicinal plant found in the tropical forests (Mabberly, 1987).

A range of phytochemicals have been isolated from the plant such as diterpenes (Witting and Guinko, 1998), water soluble polysaccharides, proteins and coumarins (Neuwinger, 1996).Various parts of the plant have been used in ethno-medicine as phyto-therapeutics for the treatment and management of numerous conditions. It has been reported to possess activities such as antimicrobial, anti-rheumatic,cytotoxic properties (Abreu et al., 1998; Abreu et al., 1999), anti-plasmodial activities (Kouyate, 2005). The plant is also used to manage leprosy and impotence (Baerts et al., 2002). 
D. microcarpum and it closely related species Detarium senegalensis are used in the treatment of syphilis, dysentery, bronchitis, leprosy, sore throat, pneumonia, diabetes, diarrhoea, malaria and meningitis in African ethno-medicine (Ebi et al., 2011; Peter et al., 2012).

The stem bark extract has also demonstrated good inhibitory activity against the Hepatitis $\mathrm{C}$ virus (Olugbuyiro et al., 2009) and also shown significant molluscidal activity against Lymnaea natalensis (Kouyate and van Damme, 2006). The plant was also shown to be effective as an anti-epileptic (Ngobum et al., 2011). The root extract of the plant has been shown to possess antidiabetic activity (Okolo et al., 2012) but there is no scientific investigation of the anti-diabetic potential of the leaves of the plant. This study is therefore aimed at investigating the antioxidant and anti-diabetic properties of various leaves extract of $D$. microcarpum using an in-vitro approach with the view to further substantiating some of the claims associated with its ethnomedicinal uses.

\section{MATERIALS AND METHODS}

All reagents used were of analytical grade and products of Sigma-Aldrich, USA. They include: Methanol, n-Hexane, Ethyl acetate, Butanol, Ammonia.All solutions were prepared in distilled water.DPPH, Rutin, Gallic acid, Folin-Ciocalteau reagent, Sodium Carbonate, Sodium Nitrite, Sodium Hydroxide, Aluminium Chloride, Ascorbic acid, Porcine pancreatic $\alpha$-amylase (EC3.2.1.1, type VI), p-nitrophenyl- $\alpha$-D glycopyranoside (pNPG), $\alpha$ Glucosidase were also obtained from Sigma-Aldrich Germany. Readings of sample absorbance were carried out using a Shimadzu $\mathrm{UV}-\mathrm{V}$ is spectrophotometer 1650 (Japan).

\section{Sample collection}

D. microcarpum Guill and Perr leaves were collected in July, 2015 from Zaria, North-West Nigeria. Authentication was done in the Department of Biological Sciences, Ahmadu Bello University, Zaria, Nigeria, by Mallam Namadi Sunusi. A voucher specimen with No. 901451 was deposited in the herbarium of the Department of Biological Sciences Ahmadu Bello University, Zaria.

\section{Preparation of extracts}

Leaves of Detarium microcarpum plant were air dried at room temperature for seven days. One thousand grams $(1000 \mathrm{~g})$ of the pulverized part were extracted exhaustively by maceration with $70 \%$ methanol at room temperature for 48 hours. A rotary evaporator was used to evaporate the extract to dryness at $40{ }^{\circ} \mathrm{C}$ to produce dried crude extract (CEDM) with yield of $160.3 \mathrm{~g}$ $(16.03 \%)$. Subsequently, slurry of the crude extract was made by dissolving it in distilled water and the slurry was transferred into a separating funnel and successive sequential extraction; was carried out to give an Ethyl acetate and aqueous fraction. The extracts were collected at each point and evaporated to dryness using a rotary evaporator at $40{ }^{\circ} \mathrm{C}$ to produce dried Ethyl acetate fraction
(EAFDM) with yield of $48.55 \mathrm{~g}(4.85 \%)$ and aqueous fraction (AQFDM) with yield of $107.92 \mathrm{~g}(10.79 \%)$. The extracts were all stored in a desiccator.

\section{Determination of Total Phenolic Content (TPC)}

Total phenolic content of the extracts were evaluated by a colorimetric method utilizing Folin-Ciocalteu reagent according to methods previously described with slight modifications (Adedapo et al., 2008; Odumosu et al., 2015).Samples containing polyphenols are reduced by the Folin-Ciocalteu reagent thereby producing blue coloured complex. The phenolic concentration of D. microcarpum extracts was evaluated from a Gallic acid calibration curve. About $500 \mu \mathrm{L}$ aliquots of 10, 20, 30, 40, 50 and $60 \mu \mathrm{g} / \mathrm{mL}$ of Methanol Gallic acid solutions were mixed with $2.5 \mathrm{ml}$ Folin-Ciocalteu regent (diluted ten-fold) and $2.5 \mathrm{~mL}(75 \mathrm{~g} / \mathrm{L})$ Sodium Carbonate. The tubes were vortexed for 10 seconds and allowed to stand for 2 hours at $25{ }^{\circ} \mathrm{C}$. After incubation at $25^{\circ} \mathrm{C}$ for 2 hours, absorbance was measured at $765 \mathrm{~nm}$ against reagent blank. Total phenolic content was expressed as mg Gallic acid equivalent using the following equation based on the calibration curve $y=0.0069 x+0.0673$, (correlation coefficient; $r^{2}=0.9947$ ), where $\mathrm{x}$ is the absorbance and $\mathrm{y}$ is the Gallic acid equivalent $(\mathrm{mg} / \mathrm{g})$. A similar procedure was adopted for the extract as described above in the preparation of calibration curve. All determinations were performed in triplicate. Total phenolic content was expressed as milligrams of Gallic acid equivalent (GAE) per $g$ of extracts

\section{Determination of Total Flavonoid Content (TFC)}

The total flavonoid content of the D. microcarpum extracts was measured by employing Aluminum Chloride colorimetric assay as reported (Odumosu et al., 2015). An aliquot $(1 \mathrm{~mL})$ of extract $(40 \mathrm{mg})$ or rutin standard solution with the following concentrations $(10,20,40,60,80$ and $100 \mu \mathrm{g} / \mathrm{mL})$ was added to a $10 \mathrm{~mL}$ volumetric flask containing $4 \mathrm{~mL}$ of distilled water. To the flask, $300 \mu \mathrm{L}$ of $5 \% \mathrm{NaNO}_{2}$ and $300 \mu \mathrm{L}$ of $10 \%$ $\mathrm{AlCl}_{3}$ were added. After 6 minutes, $2 \mathrm{~mL}$ of $1 \mathrm{M} \mathrm{NaOH}$ was added and the total volume was brought to $10 \mathrm{~mL}$ by the addition of 2.4 $\mathrm{mL} \mathrm{H}_{2} \mathrm{O}$. The solution was vortexed in order to mix the mixture thoroughly and the absorbance measured at $510 \mathrm{~nm}$ against reagent blank. The total flavonoid contents of the D. microcarpum extracts were expressed as $\mathrm{mg}$ rutin equivalents $\mathrm{mg}(\mathrm{RE}) / \mathrm{g}$ of extracts. All treatments were carried out in triplicate. The results was calculated using the standard calibration curve of rutin in methanol $\left(\mathrm{r}^{2}=0.9957\right)$ and expressed as rutin equivalents (RE $\mathrm{mg} / \mathrm{g}$ )

\section{Anti-oxidant assay \\ DPPH radical scavenging activity}

The antioxidant activity (free radical scavenging activity) of the D. microcarpum extracts on the stable radical 1,1-diphenyl2-picrylhydrazyl (DPPH) was determined according to previously described methods (Odumosu et al., 2015; Brand-Williams et al., 1995). The following concentrations of extract were prepared in 
methanol; 500, 250, 125, 62.50, 31.25, 15.62, 7.8125, 3.91, 1.95 and $0.98 \mu \mathrm{g} / \mathrm{ml}$ and $2 \mathrm{ml}$ of each concentration was mixed with $4 \mathrm{ml}$ of $50 \mu \mathrm{M}$ DPPH solution in methanol in triplicate. The mixture was vortex mixed for 10 seconds and the test tubes were incubated for 30 minutes at room temperature in the dark and the absorbance was measured at $515 \mathrm{~nm}$. Lower absorbance reading of the reaction mixture indicates higher free radical scavenging activity. Gallic acid, ascorbic acid and rutin were used as standard at the following concentrations $100,50,25,12.5,6.25,3.125$, 1.563, 0.7812, 0.391, and $0.195 \mu \mathrm{M}$. Blank solutions were prepared by mixing $2 \mathrm{ml}$ of methanol with $4 \mathrm{ml}$ of $50 \mu \mathrm{M} \mathrm{DPPH}$ solutions in methanol. The difference in absorbance between the test and the control (DPPH in methanol) was calculated and expressed as \% scavenging of DPPH radical. The capacity to scavenge the DPPH radical was calculated by using the following equation:

$\%$ inhibition $=100 \times($ Abs control - Abs sample $) /$ Abs control Finally, the $\mathrm{IC}_{50}$ value defined as the concentration was calculated from the separate linear regression plots of the mean percentage of the antioxidant activity against concentration of the test extract $(\mu \mathrm{g} / \mathrm{ml})$.

\section{$\alpha$ - glucosidase inhibitory assay}

$\alpha$-Glucosidase inhibitory activity of the extracts was assayed using the method previously described with slight modification (Worawalai et al., 2012; Damsud et al., 2013). Briefly, $10 \mu \mathrm{L}$ of the extract was mixed with $\alpha$-Glucosidase $(0.1$ $\mathrm{U} / \mathrm{ml}, 40 \mu \mathrm{L}$ ) in $1 \mathrm{mM}$ phosphate buffer ( $\mathrm{pH} \mathrm{6.9)}$ and incubates at $37^{0} \mathrm{C}$ for 10 minutes. Then $40 \mu \mathrm{L}$ of $0.1 \mathrm{mM}$ p-nitrophenyl- $\alpha \mathrm{D}$ glycopyranoside ( $\left.{ }_{\mathrm{p}} \mathrm{NPG}\right)$ was added and the mixture was then incubated for 30 minutes prior to being quenched with the addition of $100 \mu \mathrm{L} 0.1 \mathrm{M} \mathrm{Na}_{2} \mathrm{CO}_{3}$. The enzymatic activity was determined by monitoring the absorbance at $415 \mathrm{~nm}$. The percent inhibition was determined according of the equation:

$\%$ inhibition $=\left(\mathrm{A}_{\text {blank }}-\mathrm{A}_{\text {sample }}\right) / \mathrm{A}_{\text {blank }} \mathrm{x} 100$; in which $\mathrm{A}_{\text {sample }}$ and $\mathrm{A}_{\text {blank }}$ are the absorbance of solution containing ${ }_{\mathrm{p}} \mathrm{NPG}$ and $\alpha$ glucosidase with and without sample respectively. The $\mathrm{IC}_{50}$ value was determined from a plot of percentage inhibition on the $y$-axis against the sample concentration on the $\mathrm{x}$-axis. Acarbose was used as the positive control.

\section{$\alpha$-Amylase inhibitory activity}

The $\alpha$-amylase inhibition assay was performed using the chromogenic method (Ali, 2006). Porcine pancreatic $\alpha$-amylase (EC3.2.1.1, type VI) was dissolved in ice-cold distilled water. Maize starch in phosphate buffer was used as a substrate solution. According to the method, $250 \mu \mathrm{l}$ of plant extract, $125 \mu \mathrm{l}$ of phosphate buffer and $250 \mu 1$ of $\alpha$-amylase were mixed in a tube. The tubes were incubated at $37{ }^{\circ} \mathrm{C}$ for 5 minutes. After the incubation, $500 \mu \mathrm{l}$ of starch solution was added to the tubes and all tubes were incubated at $37^{\circ} \mathrm{C}$ for 5 minutes. After that, $500 \mu \mathrm{DNS}$ colour reagent solution was added to the tubes at $100^{\circ} \mathrm{C}$. After 5 minutes, $3000 \mu \mathrm{l}$ distilled water was added and tubes were cooled and $\alpha$-amylase activity was determined by measuring the absorbance of the mixture at $540 \mathrm{~nm}$. Control incubations were conducted in an identical fashion replacing plant extract with distilled water $(250 \mu \mathrm{l})$. For blank incubations, the enzyme solution was replaced with distilled water and the same procedure was carried out as above. $\alpha$-amylase inhibition assay was calculated using the formula:

$$
(\%)=\left[\left(\mathrm{A}_{540 \text { control }}-\mathrm{A}_{540 \text { extract }}\right) / \mathrm{A}_{540 \text { control }}\right] \times 100
$$

\section{Statistical Analysis}

Numerical data obtained from the study were expressed as the mean value \pm standard deviation. Statistical analysis where applicable were performed using the analysis of variance (ANOVA) followed by Tukey's post test with the aid of IBM Statistical Package for Social Scientist (SPSS 20) software. Differences were considered to be significant when $\mathrm{P}<0.05$. Halfmaximal inhibitory concentration $\left(\mathrm{IC}_{50}\right)$ was calculated from the $\%$ inhibition versus extract concentration non-linear regression curve of each extract.

\section{RESULTS}

\section{DPPH Radical Scavenging Activities of D. microcarpum Leaf Extracts and Standards}

The radical scavenging activities of the extracts were significantly higher when compared with standard gallic acid and rutin and close to ascorbic acid, indicating that the extracts are better radical scavengers (Table 2)

Inhibitory Effects of D. microcarpum Leaf Extracts againsta Amylase and $\alpha$-Glucosidase

The extracts also exhibited high levels of $\alpha$-amylase inhibitory activity with $\%$ inhibition $\left(\mathrm{IC}_{50} \mu \mathrm{g} / \mathrm{ml}\right)$ of $63.10,631.01$, and 63.50 for CEDM, EAFDM and AQFDM respectively when compared with 6.38 for acarbose. Similarly, high levels of $\alpha$ glucosidase inhibitory activity with $\%$ inhibition $\left(\mathrm{IC}_{50} \mu \mathrm{g} / \mathrm{ml}\right)$ of 158.50, 398.10, and 65.50 respectively when compared with 12.60 for standard acarbose.

\section{DISCUSSION}

Synthetic hypoglycemics have a myriad of side effects and are also limited by other challenges such as development of resistance, unresponsiveness in some patient population to mention a few. This has led to great interest in the development of plant derived hypoglycaemics which could potentially overcome some of these problems. The present study showed that extracts of $D$. microcarpum are rich sources of antioxidants as shown in Table 1. The coefficient of correlation from the gallic acid calibration curve shows a good correlation of $\mathrm{r}^{2}=0.9762$ with equation of $\mathrm{y}=$ $0.016 \mathrm{x}+0.0432$. The phenolic contents in the various leaf extracts of D. microcarpum expressed as $\mathrm{mg}$ of Gallic acid equivalent(GAE)/g of extracts (Table1) showed a significant amount of phenolics (2014.22mg, 933.33mg and $766.81 \mathrm{mg}$ of 
GAE/g of extract for EAFDM, AQFDM and CEDM respectively). Furthermore, total flavonoid content in the extracts showed high amount of flavonoids $(132.90 \mathrm{mg}, 30.50 \mathrm{mg}$ and $49.50 \mathrm{mg}$ of rutin equivalent (RE)/g of extract for EAFDM, AQFDM and CEDM respectively). The coefficient of correlation from the rutin calibration curve shows a good correlation of $r^{2}=0.9681$ with equation of $y=0.0098 x+0.0157$. Therefore, the high levels of phenolic compounds present in the various extracts are most likely responsible for the strong antioxidant activity observed in Table2 as well as the $\alpha$-glucosidase and $\alpha$-amylase inhibitory activities observed in Table 3. This correlation between total phenolic content, antioxidant potential and enzyme activities has been observed in different plants (Apostolidis et al., 2011).

Table 1: Total flavonoid and phenolic content for the various D. microcarpum leaf extracts.

\begin{tabular}{llll}
\hline Extracts & \multicolumn{1}{c}{$\begin{array}{c}\text { TFC } \\
\text { (mg RE/g } \\
\text { extract) }\end{array}$} & Extracts & $\begin{array}{c}\text { TFC } \\
\text { (mg GAE/g } \\
\text { extract) }\end{array}$ \\
\hline Crude & $49.5 \pm 6.02$ & Crude & $766.81 \pm 6.77$ \\
Ethyl acetate & $132.9 \pm 14.7$ & Ethyle acetate & $2014.22 \pm 27$ \\
Aqueous & $30.5 \pm 1.71$ & Aqueous & $933.33 \pm 2.24$ \\
\hline
\end{tabular}

Increase in the amount of free radicals and reactive oxygen species in the body without a corresponding robust antioxidant defence system leads to oxidative stress and this has been linked to the pathogenesis of degenerative diseases such as diabetes mellitus (Halliwell and Gutteridge, 1999). The ability of the extracts to scavenge DPPH was therefore evaluated (Table 2). The results revealed that all three extracts scavenged DPPH to various extents. The extracts showed good IC50 values of 8.77 $\mu \mathrm{g} / \mathrm{ml}, 15.90 \mu \mathrm{g} / \mathrm{ml}$ and $7.20 \mu \mathrm{g} / \mathrm{ml}$ for AQFDM, CEDM and EAFDM respectively as compared with those of standard gallic acid, rutin and ascorbic acid with $\mathrm{IC}_{50}$ of $75.30,47.40$ and 11.30 $\mu \mathrm{g} / \mathrm{ml}$ respectively. DPPH is a stable free radical and possesses a characteristic deep purple color in solution; antioxidants react with it thereby making it lose its characteristic deep purple color, on accepting proton from antioxidants, leading to absorption decrease ( $\lambda \max : 515-517 \mathrm{~nm})$. The degree of discoloration is therefore an indication of the scavenging ability of the antioxidant extract. Evidently, the ethyl acetate fraction had the strongest DPPH scavenging ability as shown by its very low $\mathrm{IC}_{50}$ value. This was followed by the aqueous and finally the crude extract.

Table 2: DPPH radical scavenging activities of D. microcarpum leaf extracts and standards.

\begin{tabular}{cc}
\hline Extracts & IC50 $(\boldsymbol{\mu g} / \mathbf{m L})$ \\
\hline Rutin & $47.40 \pm 0.95$ \\
Gallic acid & $75.30 \pm 1.12$ \\
Vitamin C & $11.30 \pm 0.66$ \\
Crude extract & $15.90 \pm 0.10$ \\
Ethyl acetate & $7.20 \pm 2.47$ \\
Aqueous & $8.77 \pm 2.13$ \\
\hline
\end{tabular}

Phenolic compounds which are usually produced in plants as secondary metabolites are known to possess numerous biological activities including the ability to modulate glucose metabolism by several mechanisms including inhibition of carbohydrate digesting enzymes (Hanhineva et al., 2010). The ability of the extracts to inhibit both $\alpha$-amylase and $\alpha$-glucosidase were thus tested. The results (Tables 3 ) obtained indicate that the various leaf extracts of $D$. microcarpum possess significant inhibitory activity against $\alpha$-glucosidase with the $\mathrm{IC}_{50}$ of 65.50 , 158.5 and $398.1 \mu \mathrm{g} / \mathrm{ml}$ for AQFDM, CEDM and EAFDM respectively as against $12.60 \mu \mathrm{g} / \mathrm{ml}$ for Acarbose. These figures were all significantly different as compared to Acarbose. Also, the inhibitory activity of the extracts against $\alpha$-amylase (Table 3 ) showed a similar trend.There was a statistically significant difference between the groups as the post hoc test revealed that the $\mathrm{IC}_{50}$ was statistically significantly lower for the crude and aqueous extracts as compared to the ethylacetate extract while that for Acarbose was lower than all the extracts. There was however no statistically significant difference between the $\mathrm{IC}_{50}$ value for the aqueous and the crude extract. The inhibition of carbohydrate metabolizing enzymes such as $\alpha$-amylase and $\alpha$-glucosidase impedes the breakdown of carbohydrates and subsequent glucose absorption leading to a decrease in postprandial blood glucose level (Hanhineva et al., 2010). The inhibition of these enzymes has been shown to be one of the most effective approaches for the control of hyperglycemia in type 2 diabetics (Kim et al., 2005).

Table 3: Inhibitory effect of $D$. microcarpum leaf extracts against $\alpha$-amylase and $\alpha$-glucosidase.

\begin{tabular}{ccc}
\hline Extracts & $\begin{array}{c}\text { IC50 }(\boldsymbol{\mu g} / \mathbf{m L}) \\
\boldsymbol{\alpha} \text {-amylase }\end{array}$ & $\begin{array}{c}\text { IC50 }(\boldsymbol{\mu g} / \mathbf{m L}) \\
\boldsymbol{\alpha} \text {-glucosidase }\end{array}$ \\
\hline Acarbose & $6.38 \pm 0.41^{\mathrm{a}}$ & $12.60 \pm 0.52^{\mathrm{a}}$ \\
Crude & $63.10 \pm 0.71^{\mathrm{b}}$ & $158.50 \pm 0.64^{\mathrm{b}}$ \\
Ethyl acetate & $631.01 \pm 0.32^{\mathrm{c}}$ & $398.10 \pm 0.13^{\mathrm{c}}$ \\
Aqueous & $63.50 \pm 043^{\mathrm{b}}$ & $65.50 \pm 0.21^{\mathrm{d}}$ \\
\hline
\end{tabular}

The data are expressed as mean \pm SD $n=3$ in each group. Values in the same column with different alphabets are significantly different (ANOVA followed by Tukey's post hoc test, $\mathrm{p}<0.05$ ).

\section{CONCLUSION}

The inhibition of $\alpha$-amylase and $\alpha$-glucosidase activities by the extracts of $\mathrm{D}$. microcarpum leaves observed in this study could be a possible mechanism of action supporting their use for the management of hyperglycemia. This inhibitory effect may be attributed to the action of their inherent polyphenols and flavonoids. The finding of this study therefore corroborates the traditional uses of D. microcarpum as an antidiabetic plant.However, it is imperative that further work be carried out in order to isolate and characterize the active principle(s) of the plant extracts.

\section{ACKNOWLEDGEMENT}

This study was performed in the Pharmaceutical Chemistry Research Laboratory of the Department of Pharmaceutical Chemistry, University of Jos, Nigeria and the authors are grateful to the Department for equipment support. 
Financial support and sponsorship: This study was supported by The African Centre of Excellence in Phytomedicine, Research \& Development (ACEPRD), Faculty of Pharmaceutical Sciences, University of Jos, Jos, Nigeria.

Conflict of Interests: There are no conflicts of interest.

\section{REFERENCES}

Abreu PM, Martins ES, Kayser O, Bindseil KU, Siems K, Seemann A, et al. . Antimicrobial, antitumor and antileishmania screening of medicinal plants from Guinea-Bissau. Phytomedicine. 1999; 6 (3):187195.

Abreu PM, Rosa VS, Araujo EM, Canda AB, Kayser O, Bindseil KU,et al.. Phytochemical analysis and antimicrobial evaluation of Detarium microcarpum bark extracts. Pharm Pharmacol Lett. 1998; 8 (3):107-109

Adedapo AA, Jimoh FO, Afolayan AJ, Masika PJ. Antioxidant activities and phenolic contents of the methanol extracts of the stems of Acokanthera oppositifolia and Adenia gummifera. BMC Complementary and Alternative Medicicne. 2008; 8(54): 1-7.

Akah PA, Nworu CS, Mbaoji FN, Nwabunike IA, Onyeto CA.Genus Detarium: Ethnomedicinal, phytochemical and pharmacological profile. Phytopharmacol. 2012; 3(2): 367-375.

Ali H, Houghton PJ, Soumyanath A.Alpha-amylase inhibitory activity of some Malaysian plants used to treat diabetes with particular reference to Phyllanthus amarus. J Ethnopharmacol. 2006; 107(3): 449 455 .

Apostolidis E, Li L, Lee C, Seeram NP. In vitro evaluation of phenolic-enriched maple syrup extracts for inhibition of carbohydrate hydrolyzing enzymes relevant to type 2 diabetes management. J Func Foods. 2011; 3: 100 - 106.

Baerts M, Lehmann J. Detarium microcarpum. Prelude Medicinal Plants Database. Belgium: Metatro-Intosys, Royal Museum for Central Africa, Tervuren;2002.

Brand-Williams W, Cuvelier ME, Berset C. Use of free radical method to evaluate antioxidant activity. Lebensem Wiss Technology 1995; 28: $25-30$.

Damsud T, Adisakwattana S, Phuwapraisirisan P. Three new phenylpropanoyl amides from the leaves of Piper sarmentosum and their $\alpha$-glucosidase inhibitory activities. Phytochemistry Letters. 2013; 6: 350 354 .

Ebi GC, Afieroho OE. Phytochemical and antimicrobial studies on Detarium microcarpum Guill and Perr (Caesalpinioceae) seeds coat. Afr J Biotechnol. 2011; 10(3):457-462.

Halliwell B, Gutteridge JMC. Free Radicals in Biology and Medicine. 3rd ed., Oxford University Press, Inc., New York, 1999, pp. $105-245$.

Hanhineva K, Törrönen R, Bondia-Pons I, Pekkinen J,Kolehmainen M, Mykkänen $\mathrm{H}$, et al. Impact of dietary polyphenols on carbohydrate metabolism. Int J Mol Sci 2010; 11:1365-1402.

Hostettmann K, Marston A, Ndjoko K, Wolfender J. The potential of African plants as a Source of Drug Curr Org Chem. 2000; 4: 973-1010.

Kim YM, Jeong YK, Wang MH, Lee YH, Rhee HI. Inhibitory effect of pine extract on alpha-glucosidase activity and postprandial hyperglycaemia. Nutrition 2005; 21: 756-761.

Kouyaté AM, van Damme P.Detarium microcarpum Guill. \& Perr. [online]. Record from Protabase. Schmelzer GH, Gurib-Fakim A, editors. PROTA (Plant Resources of Tropical Africa, Wageningen, The Netherlands. [Cited 2016 April 4]. Available from http://database.prota.org/search.htm
Kouyate AM. Aspects ethnobotaniques et etudea de la variability morphologique biochemique et phenologuque de Detarium microcarpum, Guill \& PCN. AU. Mali. Ph.D Thesis, Faculty of Agriculture and Applied Biological Sciences, University of Kent, Belgium. 2005.

Mabberley DJ. The Plant Book: A portable dictionary of the higher plants. Cambridge: Cambridge University Press; 1987.

Neuwinger HD. African ethnobotany:Poisons and drugs: Chemistry, Pharmacology and Toxicology. London: Chapman and Hall; 1996. p. 941.

NgoBum E, Taiwe GS, Moto FCO, Ngoupaye GT, Vougat RRN, Sakoue VD, et al.. Antiepileptic Medicinal Plants used in Traditional Medicine to Treat Epilepsy, Clinical and Genetic Aspects of Epilepsy, Dr. Zaid Afawi (Ed.). 2011; InTech Publishers, Available from: http://www.intechopen.com/books/clinical-and-genetic-aspectsofepilepsy/antiepileptic-medicinal-plants-used-in-traditional-medicine-totreat-epilepsy

Odumosu P, Ojerinde S, Egbuchiem M. Polyphenolic contents of some instant tea brands and their anti-oxidant activities. J App Pharm Sci. 2015; 5 (9): $100-105$.

Okolo CE, Akah PA, Uzodinma SU. Antidiabetic activity of the root extract of Detarium microcarpum (Fabacaee) Guill and Perr. Phytopharmacol. 2012; 3(1):12-18.

Olugbuyiro JAO, Moody JO, Hamann MT. Inhibitory activity of Detarium microcarpum extract against hepatitis C virus. Afr J Biomed Res. 2009; 12(2):146 - 151.

Shaw JE, Sicree RA, Zimmet PZ. Global estimates of the prevalence of diabetes for 2010 and 2030. Diabetes Res Clin Pract. 2010; 87: 4-14.

TraBi FH, Guy MI, N“Gaman KCC, Mohou CHB. Etudes de quelques plantes thérapeutiques utilisées dans le traitement de $1^{\text {" }}$ hypertension et du diabète: deux maladies émergentes en Côte d"Ivoire. Sciences et nature. 2008; 5: 39-48.

Witting R, Guinko S. Plantes medicinales el leurs usages clez less mossis de sampodogo et Oueguedo. Etudes flores et vegetation. Burking Faso 4. verlas Natur and Wissenschaft. Germany: Solingen; 1998. p. 144.

Worawalai W, Rattanangkool E, Vanitcha A, Phuwapraisirisan $\mathrm{P}$, Wacharasindhu S. Concise synthesis of (+)-conduritol $\mathrm{F}$ and inositol analogues from naturally available (+)-proto-quercitol and their glucosidase inhibitory activity. Biorg Med Chem Lett. 2012; 22 (4): 1538 -1540 .

World Health Organization (WHO). Definition, Diagnosis and Classification of Diabetes Mellitus and its Complications. Report of WHO Consultation, Geneva. 1999. Series 66.

\section{How to cite this article:}

David J, Afolabi EO, Ojerinde SO, Olotu PN, Agwom FM, Ajima U. In-Vitro Antidiabetic and Antioxidant Activity of Various Leaf Extracts of Detarium microcarpum. J App Pharm Sci, 2017; 7 (06): $127-131$ 